\title{
Two new species and new records of many-plumed moths of the genus Microschismus Fletcher, 1909 (Lepidoptera: Alucitidae) from the Republic of South Africa with corld catalogue of the genus
}

\author{
Ава новых вида и новые данные по веерокрылкам рода \\ Microschismus Fletcher, 1909 (Lepidoptera: Alucitidae) Южкной Африки
}

\section{Petr Ustjuzhanin ${ }^{1,2^{*}}$, Vasiliy Kovtunovich ${ }^{3}$, Alexander Streltzov ${ }^{4}$ П.Я Устюжканин ${ }^{1,2^{*}}$, В.Н. Ковтунович ${ }^{3}$, А.Н. Стрельцов ${ }^{4}$}

\footnotetext{
${ }^{1}$ Altai State University, Lenina 61, RF-656049 Barnaul, Russia. E-mail: petrust@mail.ru.

2 Biological Institute, Tomsk State University, Lenina Prospekt 36, Tomsk 634050, Russia. E-mail: petrust@mail.ru.

${ }^{3}$ Moscow Society of Nature Explorers, Bolshaya Nikitskaya 2, Moscow 125009, Russia. E-mail: vasko-69@mail.ru.

${ }^{4}$ Herzen State Pedagogical University of Russia, Moika Emb. 48, Saint-Petersburg 191186, Russia. E-mail: streltzov@mail.ru

1 Алтайский государственный университет, пр. Ленина 61, Барнаул 656049, Россия.

2 Томский государственный университет, пр. Ленина 33, Томск 634050, Россия.

3 Московское общество испытателей природы, ул. Большая Никитская 6, Москва 103009, Россия.

${ }^{4}$ Российский государственный педагогический университет им. А.И. Герцена, наб. реки Мойки 48, Санкт-Петербург 191186, Россия.

" Corresponding author
}

KEY WORDS: Alucitidae, Microschismus, many-plumed moths, Republic of South Africa, new species, new data. КЛЮЧЕВЫЕ СЛОВА: Alucitidae, Microschismus, веерокрылки, Южно-Африканская Республика, новые виды, новые данные.

ABSTRACT. The article describes two new species of many-plumed moths from South Africa: Microschismus yakovlevi Ustjuzhanin et Kovtunovich sp.n. and Microschismus alida Ustjuzhanin et Kovtunovich sp.n. We allocate the lectotype and paralectotype from the heterogeneous type series of two syntypes of Microschismus premnias Meyrick, 1913, where the second one proved to be the previously described Microschismus antennatus Fletcher, 1909. The image of M. premnias lectotype adult is given for the first time, as well as the image of the female genitalia from the latest collections. The new data on the distribution of the species of this genus are also provided.

РЕЗЮМЕ. Описаны два новых вида веерокрылок из Южной Африки: Microschismus yakovlevi Ustjuzhanin et Kovtunovich sp.n. и Microschismus alida Ustjuzhanin et Kovtunovich sp.n. Из гетерогенных синтипов Microschismus premnias Meyrick, 1913 выделяются лектотип и паралектотип, второй оказался описанным ранее Microschismus antennatus Fletcher, 1909. Впервые приводится изображение имаго лектотипа M. premnias, а также описание и изображение гениталий самки из последних сборов. Приводятся новые сведения по распространению видов данного рода.

\section{Introduction}

The many-plumed moths genus Microschismus Fletcher, 1909 (Type species Microschismus antennatus Fletcher, 1909, by monotypy) included eight valid species [Ustjuzhanin, Kovtunovich, 2011] from Southern Africa (South Africa and Zimbabwe). As a result of new studies and examinations of materials from Russian expeditions of 2018 and 2019 in the Republic of South Africa, we have found two more species new to science and supplemented the data on the genus distribution. The new supplementary material allowed solving the nomenclature problem of the species Microschismus premnias Meyrick, 1913. In the revision of the genus Microschismus [Ustjuzhanin, Kovtunovich, 2011] there were shown the syntypes of $M$. premnias: photo of the adult and the male and female genitalia. Edward Meyrick described $M$. premnias on the series of two specimens: a female from Northern Cape: Three Sisters, 6.iii.1911, A.J.T. Janse and a male from KwaZuluNatal: Pinetown, A.J.T. Janse [Meyrick, 1913]. As it has been found, they belong to different species. As the lectotype of $M$. premnias we allocate the male. Thus, the type habitat of the species M. premnias is KwaZuluNatal: Pinetown. The female (noted as paralectotype)

How to cite this article: Ustjuzhanin P.Ya., Kovtunovich V.N., Streltzov A.N.2020. Two new species and new records of many-plumed moths of the genus Microschismus Fletcher, 1909 (Lepidoptera: Alucitidae) from the Republic of South Africa with corld catalogue of the genus // Russian Entomol. J. Vol.29. No.4. P.423-427. doi: 10.15298/rusentj.29.4.10 
belongs to M. antennatus Fletcher, 1909

Abbreviations: CUK - Collection by P. Ustjuzhanin and V. Kovtunovich (Novosibirsk and Moscow, Russia); NHMUK - Natural History Museum, United Kingdom, London; OUMNH - Oxford University Museum of Natural History (Oxford, Great Britain); TMSA — Ditsong Museum of Natural History (Transvaal Museum) Pretoria, South Africa; ZISP - Zoological Institute of Russian Academy of Science St. Petersburg.

\section{Results}

\section{Microschismus yakovlevi}

Ustjuzhanin et Kovtunovich, sp.n.

$$
\text { Figs 1-2. }
$$

TYPE MATERIAL: Holotype, O', (ZISP, gen. pr. Nr. 1922) SOUTH AFRICA: Western Cape, $27 \mathrm{~km}$ E Calitzdorp, Amber Lagoon, $33^{\circ} 37^{\prime} \mathrm{S}, 21^{\circ} 53^{\prime} \mathrm{E}$, h $258 \mathrm{~m}, 05-08$.iii.2018, Kovtunovich V., Udovichenko P., Yakovlev R. leg.

DESCRIPTION. External characters. Head and tegulae light-grey, thorax noticeably darker. Labial palpi grey, three time longer than longitudinal eye diameter. Antennae simple, thin, dark-grey. Wingspan 14,5 mm. Wings grey. Distinct dark points at cleft bases of all wings. Wide dark-grey band along all lobes medially. Dark-grey band on wings distally.
Tips of all lobed finishing with distinct black spots. Hind legs white, ends slightly blackened.

Male genitalia. Uncus ellipsoid, distally wide. Gnathos narrow, apically sharp. Valves narrow, straight, basally with very short processes. Anellus arms thin, straight, equal to valves in length. Saccus narrow, curves and sharp. Aedeagus straight, with narrow spiky cornutus distally.

DIAGNOSIS. In the wings color and genital structure, the new species differs from all the known species in the genus Microschismus.

Flight period: March.

ETYMOLOGY. The species is named after Russian entomologist Roman Yakovlev, member of the expedition to South Africa in 2018, when the new species was found.

\section{Microschismus alida} Ustjuzhanin et Kovtunovich, sp.n. Figs 3-4.

TYPE MATERIAL: Holotype, ơ', (ZISP, gen. pr. Nr. 1923), SOUTH AFRICA: Free State, Golden Gate Highlands Nat. Park, $28^{\circ} 30^{\prime} \mathrm{S}, 28^{\circ} 34^{\prime} \mathrm{E}$, h $1870 \mathrm{~m}$, 26. ii.-04.iii.2018, Kovtunovich V.,

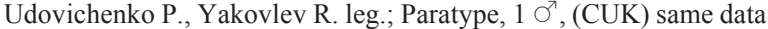
as holotype, Kovtunovich V., Udovichenko P., Yakovlev R. leg.

DESCRIPTION. External characters. Head, thorax and teguale white. Labial palpi white, brown only from outside, apically tapered. Five times longer than longitudinal eye

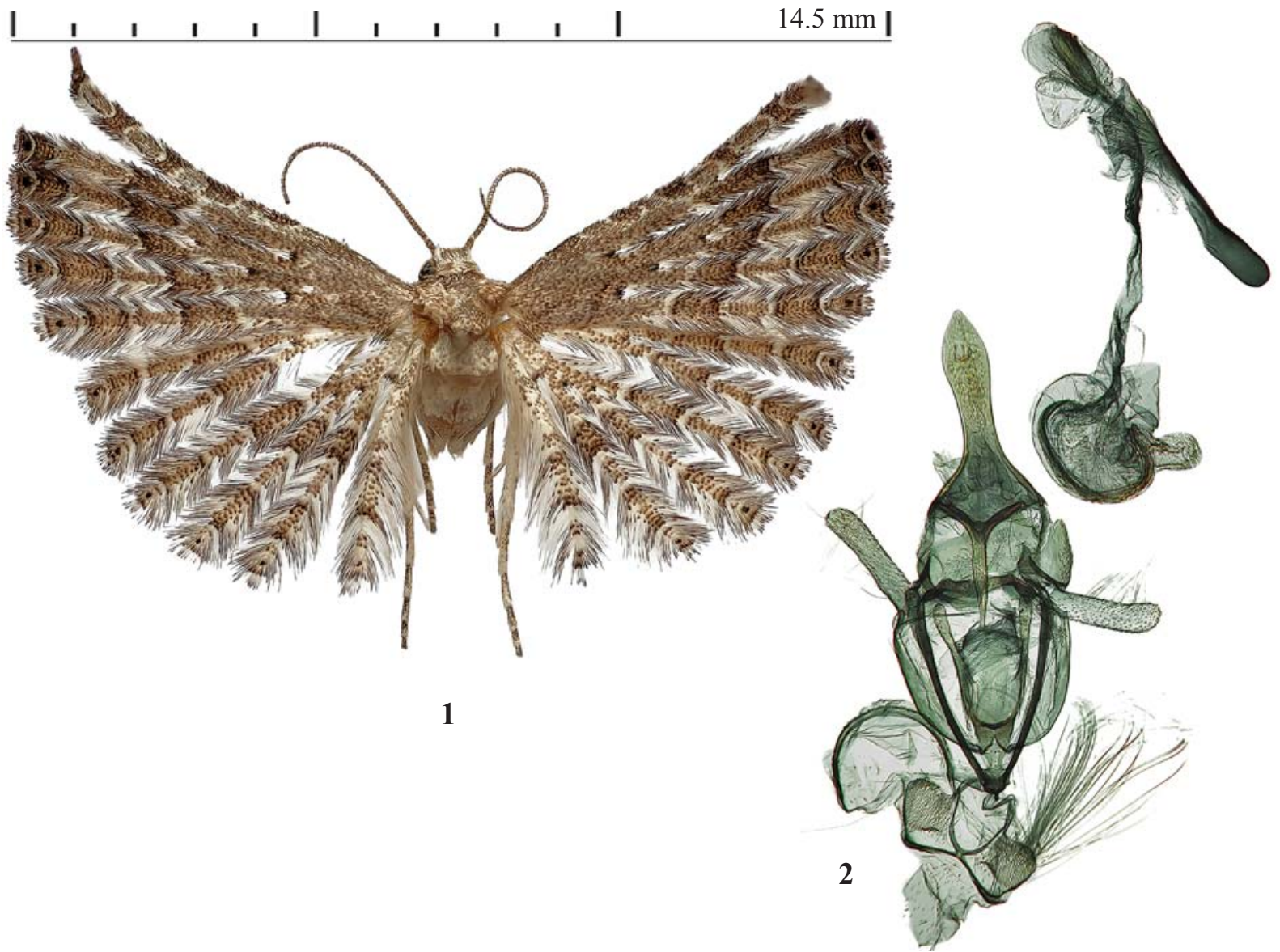

Figs 1-2. Microschismus yakovlevi Ustjuzhanin et Kovtunovich, sp.n.: 1 - adult (Holotype, ZISP); 2 - male genitalia (Holotype, ZISP, gen.pr. Nr. 1922).

Рис. 1-2. Microschismus yakovlevi Ustjuzhanin et Kovtunovich, sp.n.: 1 - имаго (голотип, ZISP); 2 - гениталии самца (голотип, ZISP, gen.pr. Nr. 1922). 
diameter. Antennae finely serrated, yellowish-grey, basally distinctly darkened with brown scales. Wingspan 16-17 mm. Fore wings greyish-white with chaotically dispersed dark brown points and spots. Series of dark brown longitudinal spots along costa of fore wing. Fore wing basally darkened. Tips of all lobes finishing with distinct dark brown spots. Hind wings greyish-white, noticeably lighter than fore wings. Legs pale yellow.

Male genitalia. Uncus wide, apically bluntly rounded. Gnathos narrow, long, noticeably longer than uncus, apically sharp. Valves basally wide, then narrowing, with short finger-like processes before the narrowing. Anellus arms very wide, lobe-like. Saccus straight. Aedeagus short, robust, without cornuti.

DIAGNOSIS. In the wings color and male genital structure, the species is similar to Microschismus reginus Ustjuzhanin et Kovtunovich, 2011, but differs in the lighter color and smaller number of the points and spots on the fore wings. In the male genitalia, the new species differs from $M$. reginus in its wide lobe-like anellus arms, the narrower uncus which is bluntly rounded apically, while in $M$. reginus the anellus arms are narrow, not lobe-like, the uncus is significantly wider and has a notch on tip.

Flight period: February-March.

ETYMOLOGY. The species is named after Alida Myburgh (Springbok, Rep. S. Africa).

\section{Microschismus antennatus Fletcher, 1909}

Microschismus antennatus Fletcher 1909: 253-254. Type 1ocality: Bothaville [Free State, South Africa]. Type material (holotype) in OUMNH, examined.

Microschismus ctenias Meyrick, 1911: 222. Type locality: 'Nggeleni' [Ngqeleni, Eastern Cape, South Africa]. Type material (holotype) in TMSA, examined.

Microschismus columella Meyrick, 1927: 373. Type locality: Haenertsburg [Limpopo, South Africa]. Type material (holotype) in TMSA, examined.

Microschismus cato Meyrick, 1927: 374. Type locality: Mahuba's Kloof [Limpopo, South Africa]. Type material (holotype) in TMSA, examined.

MATERIAL EXAMINED. $1 \sigma^{\top}$, SOUTH AFRICA: Free State, Golden Gate Highlands Nat. Park, 28 $30^{\prime}$ S, 28 $8^{\circ} 34^{\prime}$ E, h 1870 m, 26. ii.-04.iii.2018; $1 \sigma^{7}$, SOUTH AFRICA: KwaZulu-Natal, Vernon Crookes Nat. Park, $30^{\circ} 16^{\prime} \mathrm{S}, 30^{\circ} 36^{\prime} \mathrm{E}$, h $410 \mathrm{~m}, 11-14$. iii.2018, Kovtunovich V., Udovichenko P., Yakovlev R. leg.

DISTRIBUTION. Rep. S. Africa: Free State, Eastern Cape, Northern Cape, Mpumalanga, Limpopo, KwaZuluNatal.

REMARKS. The adult and the female genitalia of this species are illustrated as $M$. premnias in our previously published article [Ustjuzhanin, Kovtunovich, 2011].

\section{Microschismus cymatias Meyrick, 1918}

Microschismus cymatias Meyrick 1918: 35. Type locality: Pretoria, South Africa. Type material (holotype) in TMSA, examined.

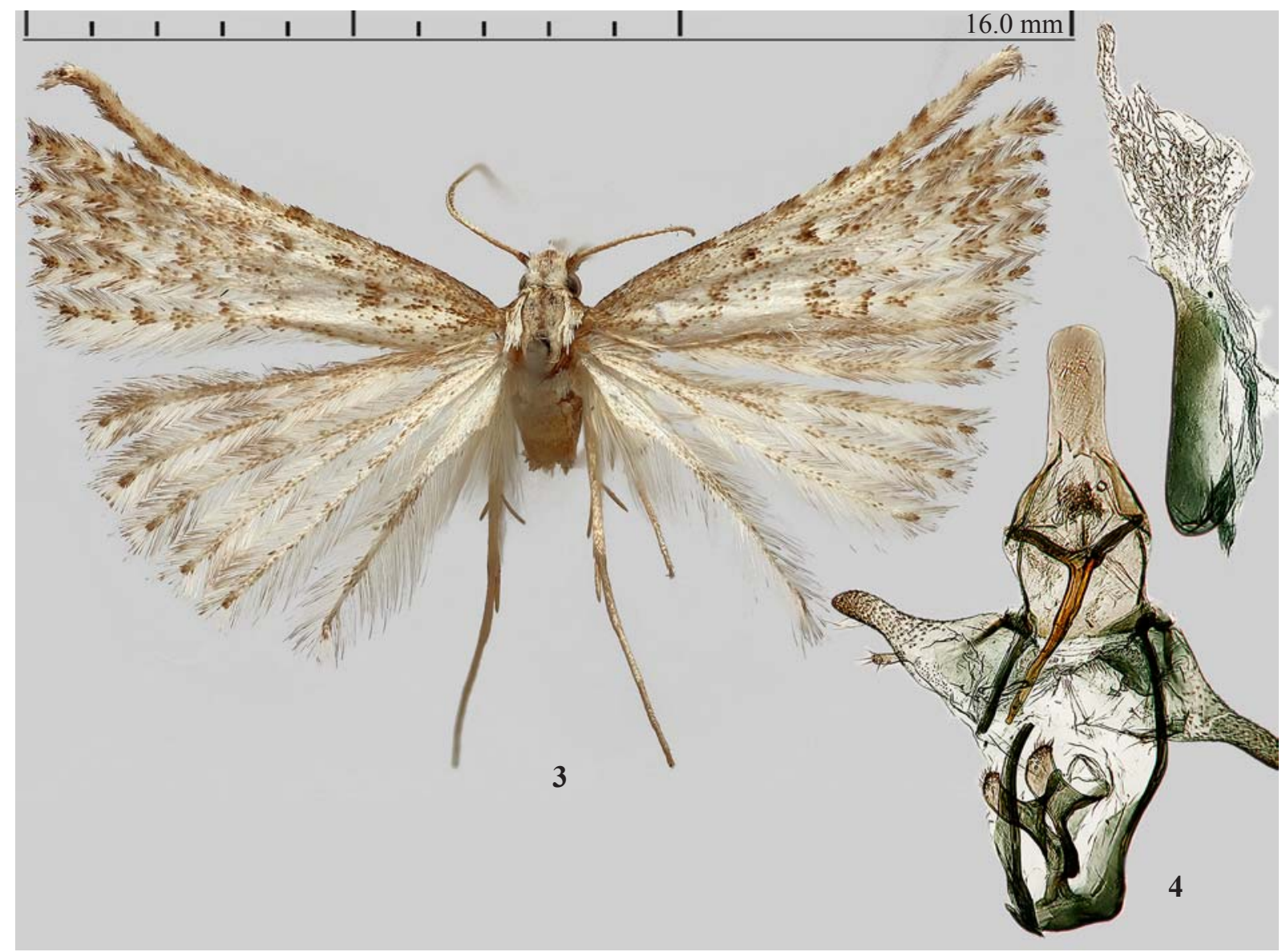

Figs 3-4. Microschismus alida Ustjuzhanin et Kovtunovich, sp.n.: 3 - adult (Holotype, ZISP); 4 - male genitalia (Holotype, ZISP, gen.pr. Nr. 1923).

Рис. 3-4. Microschismus alida Ustjuzhanin et Kovtunovich, sp.n.: 3 — имаго (голотип, ZISP); 4 — гениталии самца (голотип, ZISP, gen.pr. Nr. 1923). 
MATERIAL EXAMINED. 5 ex., SOUTH AFRICA: Free State, Golden Gate Highlands Nat. Park, 2830'S, 28³4'E, h 1870 m, 26.ii04.iii.2018, Kovtunovich V., Udovichenko P., Yakovlev R. leg.

DISTRIBUTION. Rep. S. Africa: Gauteng, Mpumalanga, Free State, Northern Cape, Western Cape [Ustjuzhanin, Kovtunovich, 2017].

Microschismus fortis (Walsingham, 1881)

Alucita fortis Walsingham, 1881: 284. Type locality: ?Zululand, South Africa. Type material (holotype) in NHMUK, examined.
Microschismus serricornis Meyrick, 1914: 187. Type locality: Pretoria, South Africa. Type material (syntypes) in TMSA, examined. MATERIAL EXAMINED. $1 \sigma^{\top}$, SOUTH AFRICA: Free State, Golden Gate Highlands Nat. Park, 2830'S, 2834'E, h 1870 m, 26.ii-04.iii.2018, Kovtunovich V., Udovichenko P., Yakovlev R. leg.; $1 \sigma^{7}$, SOUTH AFRICA: KwaZulu Natal, Ukahlamba Drakensberg Park, Giant's Castle, 29¹6' S, 29³1'E, h 1770 m, 1922.ii.2019, Kovtunovich V. \& Udovichenko P. leg.

DISTRIBUTION. Rep. S. Africa: KwaZulu Natal, Gauteng, Northern Cape [Ustjuzhanin, Kovtunovich, 2017], Free State.

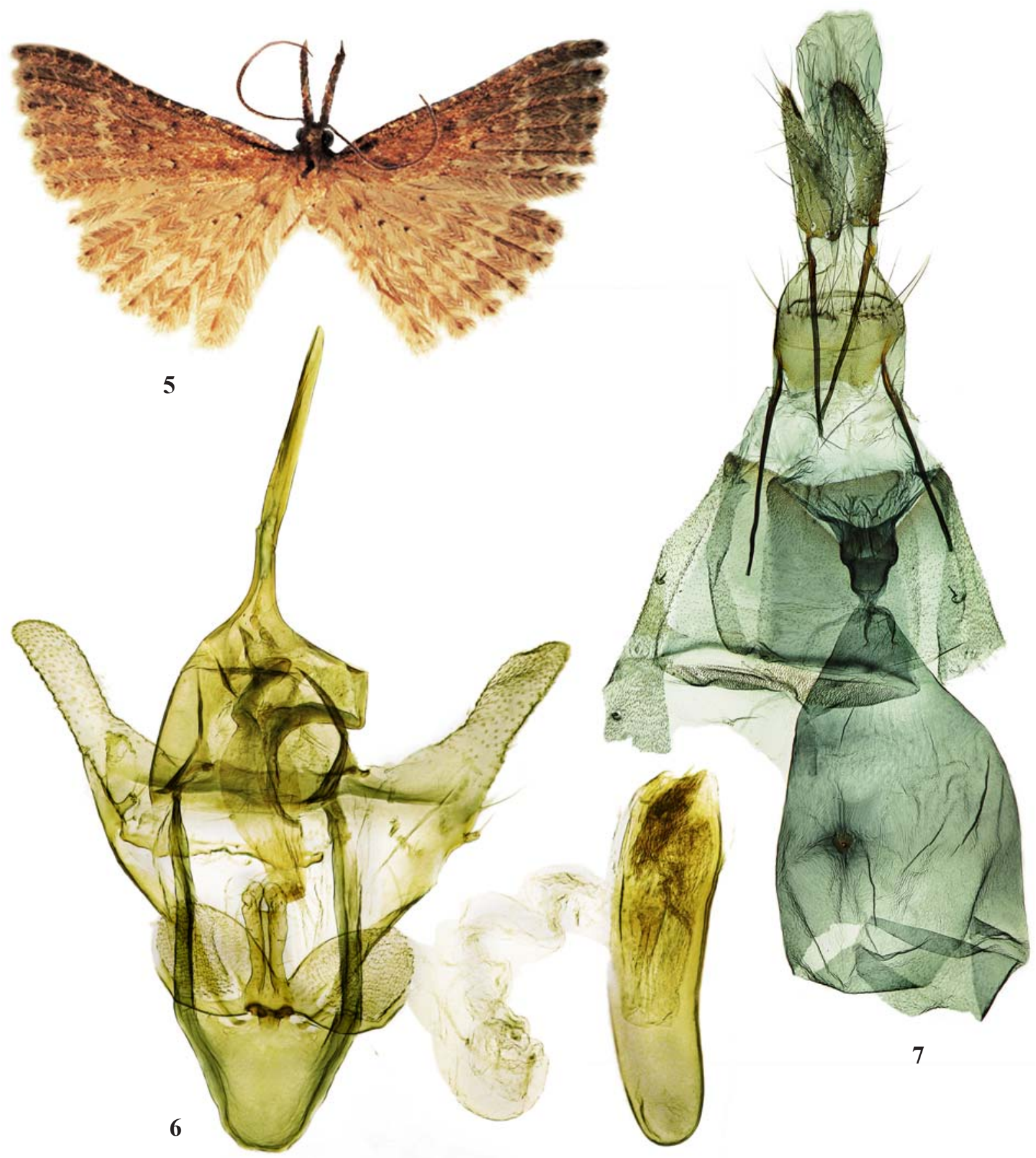

Figs 5-7. Microschismus premnias Meyrick, 1913: 5 - adult (Lectotype, TMSA); 6 - male genitalia (Lectotype, TMSA gen.pr. Nr. 15966); 7 - female genitalia (CUK, gen.pr. Nr. 318).

Рис. 5-7. Microschismus premnias Meyrick, 1913: 5 — имаго (лектотип, TMSA); 6 — гениталии самца (лектотип, TMSA gen.pr. Nr. 15966); 7 - гениталии самки (CUK, gen.pr. Nr. 318). 
REMARKS. Recorded for Free State for the first time.

Microschismus lenzi

Ustjuzhanin et Kovtunovich, 2011

Microschismus lenzi Ustjuzhanin et Kovtunovich, 2011: 564. Type locality: Zimbabwe, Manicaland, Bvumbe, Seldomseen Holliday cottages, $19^{\circ} 06^{\prime} \mathrm{S}, 32^{\circ} 45^{\prime} \mathrm{E}$.

MATERIAL EXAMINED. $1 \sigma^{\prime}$, SOUTH AFRICA: KwaZulu Natal, Vernon Crookes Nat. Reserve, 30 $30^{\prime} \mathrm{S}, 30^{\circ} 36^{\prime} \mathrm{E}$, h 410 m, 01-03.iii.2019, Kovtunovich V. leg.

DISTRIBUTION. Zimbabwe: Manicaland; Rep. S. Africa: KwaZulu Natal.

REMARKS. Recorded for Rep. S. Africa for the first time.

\section{Microschismus premnias Meyrick, 1913}

\section{Figs 5-7.}

Microschismus premnias Meyrick 1913: 269. Type locality: KwaZulu-Natal: Pinetown. Type material (lectotype, designated here) in TMSA, examined.

MATERIAL EXAMINED. $5 \sigma^{\top} \sigma^{\top}, 1$ ㅇ, (CUK, gen. pr. Nr. 318), SOUTH AFRICA: Free State, Golden Gate Highlands Nat. Park, $28^{\circ} 30^{\prime} \mathrm{S}, 28^{\circ} 34^{\prime} \mathrm{E}$, h 1870 m, 26.ii-04.iii.2018, Kovtunovich V. Udovichenko P., Yakovlev R. leg.

Female genitalia. Papillae anales long, narrow. Posterior apophyses slightly shorter than anterior ones. Antrum wide, goblet-like. Ductus very short, immediately turning into oval bursa copulatrix. Signum round, sclerotized, well expressed, located in center of bursa.

DISTRIBUTION. Rep. S. Africa: KwaZulu Natal, Free State.

REMARKS. Syntype (male from Pinetown, Natal [KwaZulu-Natal: South Africa]) designated here as lectotype of $M$. premnias Meyrick, 1913. Second syntype (female from Three Sisters, 6.iii.1911, A.J.T. Janse [Northern Cape, South Africa]) designated here as paralectotype, refers to the previously described $M$. antennatus Fletcher, 1909. Recorded for Free State for the first time.

Microschismus sceletias Meyrick, 1911

Microschismus sceletias Meyrick 1911: 222. Type locality: Woodb[ush]. Vill[age]. [Limpopo, South Africa].
MATERIAL EXAMINED. 1 ๑, SOUTH AFRICA: KwaZulu Natal, Mhlopeni, $29^{\circ} 00^{\prime} \mathrm{S}, 30^{\circ} 24^{\prime} \mathrm{E}$, h 875 m, 22-25.ii.2019, Kovtunovich V. leg.

DISTRIBUTION. Rep. S. Africa: Limpopo, Gauteng [Ustjuzhanin, Kovtunovich, 2017], KwaZulu Natal.

NOTE. Recorded for KwaZulu-Natal for the first time.

\section{Microschismus sterkfonteini}

Ustjuzhanin et Kovtunovich, 2011

Microschismus sterkfonteini Ustjuzhanin et Kovtunovich, 2011: 568. Type locality: $28^{\circ} 23^{\prime} \mathrm{S}, 2^{\circ} 23^{\prime} \mathrm{E}, 20 \mathrm{~km} \mathrm{~S}$ of Harrismith, Sterkfontein Dam, South Africa.

MATERIAL EXAMINED. 11 ex., SOUTH AFRICA: KwaZulu Natal, Ukahlamba Drakensberg Park, Giant's Castle, $29^{\circ} 16^{\prime} \mathrm{S}, 29^{\circ} 31^{\prime} \mathrm{E}$, h 1770 m, 19-22.ii.2019, Kovtunovich V. \& Udovichenko P. leg.

DISTRIBUTION. Rep. S. Africa: Free State, KwaZulu Natal [Ustjuzhanin, Kovtunovich, 2017].

Acknowledgements. The authors are grateful to the colleagues-entomologists for their assistance in collecting the materials: Pavel Udovichenko, Anatoly Marusov, Anatoly Krupitsky (all Moscow, Russia). We are especially indebted to R.Yakovlev (Barnaul, Russia) for his assistance in collecting the specimens and valuable advice in writing the article. We also express our gratitude to Sergey Reshetnikov (Novosibirsk, Russia) for providing photos of the adults. The authors are grateful to Anna Ustjuzhanina (Tomsk, Russia) for language improvements.

\section{References}

Meyrick E. 1913. Descriptions of South African Micro-Lepidoptera. IV // Annals of the Transvaal Museum. Vol.3. No.4. P.267-336. Ustjuzhanin P., Kovtunovitch V. 2011. A revision of the genus Microschismus Fletcher, 1909 // African Invertebrates. Vol.52. P.557-570.

Ustjuzhanin P., Kovtunovich V. 2017. Many-plumed moths of the republic of South Africa (Lepidoptera, Alucitidae) // Ukrainian Journal of Ecology. Vol.7. No.4. P.640-643. 